\title{
Relative bioavailability of iron from organic sources for weanling piglets
}

\section{Biodisponibilidade relativa do ferro de fonte orgânica para leitões desmamados}

\author{
Fabiana Golin Luiggi ${ }^{1 *}$; Dirlei Antonio Berto ${ }^{2}$; Gabriela de Mello ${ }^{1}$; \\ Lucio Vilela Carneiro Girão ${ }^{1}$; Cássio Cordeiro Ensá Junqueira Villela ${ }^{3}$; \\ Vivian Lo Tierzo ${ }^{1}$; Alessandro Borges Amorim ${ }^{1}$; Messias Alves da Trindade Neto ${ }^{4}$
}

\begin{abstract}
Some authors consider minerals from organic sources more bioavailable for pig nutrition in comparison with inorganic sources. To evaluate the relative iron bioavailability from the organic source iron carbo-amino-phospho-chelate (ICAPC) to weanling piglets, it was conducted an experiment with 126 commercial piglets, using iron sulfate monohydrate (S) as standard. The experiment had a randomized block design with seven treatments (diet without adding specific source of iron, diet with 50, 100 and $150 \mathrm{ppm}$ iron from $\mathrm{S}$ and diet with 50, 100 and $150 \mathrm{ppm}$ iron from ICAPC), six replications and three animals per experimental unit. Performance parameters (average daily gain - ADG, feed:gain ratio - F:G) and blood variables (hemoglobin - Hb, hematocrit - Ht, transferrin - TR, latent iron-binding capacity - LIBC, total iron-binding capacity - TIBC, serum iron - Fe and transferrin saturation index TSI) were evaluated. At the end of the experiment a piglet from each experimental unit was slaughtered and its liver and spleen removed for assessment of iron concentration by flame atomic absorption spectrometry (FAAS). The evaluated sources of iron yielded similar results for the variables of interest, but the increase in iron intake was followed by a linear increase in ADG, $\mathrm{Hb}, \mathrm{Ht}, \mathrm{Fe}$ and TSI as well as a linear decrease in the values of F:G, TR, LIBC and TIBC. Iron bioavailabilities from both ICAPC and $\mathrm{S}$ sources are similar for weanling piglets.
\end{abstract}

Key words: Chelated mineral, hemogram, iron deficiency anemia, nutrition, swine

\section{Resumo}

Alguns autores consideram os minerais de fontes orgânicas mais biodisponíveis para a nutrição de suínos quando comparados à minerais de fontes inorgânicas. Para avaliar a biodisponibilidade relativa do ferro proveniente da fonte orgânica carbo-amino-fosfo-quelato de ferro (CAFQF), foi conduzido um experimento com 126 leitões de linhagem comercial, utilizando o sulfato de ferro (S) como padrão. $\mathrm{O}$ delineamento experimental foi inteiramente casualizado com sete tratamentos (dieta sem adição de fonte específica de ferro, dietas com 50, 100 e 150 ppm de ferro na forma de $\mathrm{S}$ e dietas com 50, 100 e $150 \mathrm{ppm}$ de ferro na forma de CAFQF), seis repetições e três animais por unidade experimental.

\footnotetext{
${ }^{1}$ Discentes do Curso de Pós-Graduação em Zootecnia, Faculdade de Medicina Veterinária e Zootecnia, UNESP, Botucatu, SP, Brasil. E-mail: fabi.luiggi@yahoo.com.br; gabimello@zootecnista.com.br; luciogirao@yahoo.com; vivilotierzo@gmail.com; alessandrozoo@gmail.com

${ }^{2}$ Prof., Dept ${ }^{\circ}$ de Produção Animal, UNESP, Botucatu, SP, Brasil. E-mail: dirleiberto@fmvz.unesp.br

${ }^{3}$ Discente do Curso de Graduação em Zootecnia, UNESP, Botucatu, SP, Brasil. E-mail: cassio.villela@hotmail.com

${ }^{4}$ Prof., Dept ${ }^{\mathrm{o}}$ de Nutrição e Produção Animal, Faculdade de Medicina Veterinária e Zootecnia, USP, Pirassununga, SP, Brasil. E-mail: messiastn@usp.br

* Author for correspondence
} 
Parâmetros de desempenho (ganho de peso médio diário - GMD, conversão alimentar - CA) e variáveis sanguíneas (hemoglobina - $\mathrm{Hb}$, hematrócrito - Ht, transferrina - TR, capacidade latente de ligação do ferro - CLLF, capacidade total de ligação do ferro - CTLF, ferro sérico - FS e índice de saturação da transferrina - IST) foram avaliados. Ao final do experimento um leitão por unidade experimental foi abatido para a retirada do fígado e braço para avaliação da concentração de ferro por espectrometria de absorção atômica em chama (FAAS). As fontes de ferro avaliadas apresentaram resultados semelhantes para as variáveis de interesse, mas o aumento da ingestão de ferro resultou em aumento linear nos valores de GMD, Hb, Ht, FS e IST e redução linear nos valores de CA, TR, CLLF e CTLF. Para leitões desmamados a biodisponibilidade do ferro proveniente do CAFQF é similar à do $\mathrm{S}$.

Palavras-chave: Anemia ferropriva, hemograma, mineral quelatado, nutrição, suínos

\section{Introduction}

Taking part in essential biochemical processes in animal's body, minerals affect productive and reproductive performance, making supplementation indispensable for pigs.

Just providing animals with minerals does not guarantee its absorption and employment. Sources must also feature high bioavailability. Pig mineral supplementation has been traditionally done with inorganic salts. However, mineral organic sources from industrial processes that bind one or more metals to one or more organic molecules are being used lately (ACDA; CHAE, 2002).

Iron is a trace mineral of high dietary requirement, acting in blood and muscle oxygen transport, electron transfer, cell proliferation, production and deposition of oxygen radicals and peroxides, hormone synthesis and immune defense (LINDER, 1991).

Piglets in confinement require mineral supplementation because of the reduced stock of iron in the liver of newborns and of the low level of iron in milk. Free access to products containing chelated iron prevents the onset of anemia in piglets, resulting in a growth comparable to that afforded by the injection of iron dextran (SVOBODA; DRABEK, 2003).

Iron deficiency can manifest itself in other stages of the pig's life whenever iron availability is reduced with respect to the level required for hemoglobin formation thus causing supplementation of postweaning diets to be required as well $(\mathrm{CHURCH}$; POND, 1982; MCDOWELL, 2003).
Some researches shows that intestinal absorption is greater for iron chelated with amino acids than for inorganic sources (ASHMEAD, 1996; SCHIAVON et al., 2000). However, further studies are required to evaluate the bioavailability for pigs of iron from organic sources.

The goal of the present study was to evaluate the relative bioavailability for weanling piglets of iron from an organic source (iron carbo-amino-phosphochelate - ICAPC) using iron sulfate monohydrate (S) as standard.

\section{Material and Methods}

\section{Animal study}

The experiment was approved by FMVZ/UNESP committee on animal experimentation ethics (Comissão de Ética no Uso de Animais - CEUA, Faculdade de Medicina Veterinária e Zootecnia UNESP) as pursuant to its animal experimentation ethical principles. The experimental facilities were located in the city of Botucatu, state of São Paulo, Brazil, at coordinates $22^{\circ} 49^{\prime} \mathrm{S}$ lat, $48^{\circ} 23^{\prime} \mathrm{W}$ lon and at an altitude of $600 \mathrm{~m}$.

The study employed 126 commercial pigs (barrows and gilts) weaned at 21 days old and with a mean weight of $6.0 \mathrm{~kg} \pm 0.94 \mathrm{~kg}$. An iron supplement of only one fourth of the recommended dose (50 mg / animal) was injected on the third day after birth.

After weaning, the piglets were housed in a nursery room, in suspended pens with a partially 
slatted floor, equipped with feeders, nipple drinkers and lampshade-like electrical heaters. Side blinders maintained the desired level of internal ventilation in the room and three maximum and minimum thermometers were set up to help in the daily on-off control of the heating sources.

In the first nine days after weaning (21-30 days old), animals underwent a period of iron depletion where they received a pre-starter ad libitum diet with a mineral premix without a specific source of iron (Tables 1 and 2). The iron content of the prestarter diet was $137 \mathrm{ppm}$.
At the end of the depletion period, the mean levels of hemoglobin - $\mathrm{Hb}$ and hematocrit - Ht reached 9.8 $\mathrm{g} / \mathrm{dL}$ and $32.6 \%$, respectively, which is close to the lower limit of the range considered normal for pigs - 10.0 to $16.0 \mathrm{~g} / \mathrm{dL}$ for $\mathrm{Hb}$ and 32 to $50 \%$ for $\mathrm{Ht}$, as established by Weiss and Wardrop (2010).

Monitoring of $\mathrm{Hb}$ and $\mathrm{Ht}$ over the depletion period was based on blood samples from 30 animals picked by lot when entering the nursery. During the iron depletion period two blood samples were taken from thirty animals and on the ninth day blood samples were taken from all piglets.

Table 1. Percentage composition of pre-starter and starter diets.

\begin{tabular}{|c|c|c|}
\hline Ingredients & Pre-starter $(\%)$ & Starter $(\%)$ \\
\hline Ground corn & 54.6243 & 56.5765 \\
\hline Soybean meal & 20.3000 & 25.5000 \\
\hline Skimmed milk poder & 11.0000 & 7.5000 \\
\hline Sugar & 1.5000 & 1.0000 \\
\hline Maltodextrin & 7.3000 & 4.7300 \\
\hline Soybean oil & 1.0000 & 1.1200 \\
\hline Ground rice hull ${ }^{1}$ & 0.0732 & 0.0750 \\
\hline Limestone & 0.4600 & 0.6100 \\
\hline Dicalcium phosphate & 1.4200 & 1.2400 \\
\hline Sodium chloride & 0.4000 & 0.4000 \\
\hline L-Lysine $\mathrm{HCl} 78$ \% & 0.7100 & 0.5050 \\
\hline Dl-Methionine $99 \%$ & 0.1150 & 0.0660 \\
\hline L-Threonine $98 \%$ & 0.3400 & 0.2150 \\
\hline L-Tryptophan $98 \%$ & 0.0700 & 0.0130 \\
\hline Zinc Oxide $75 \%$ & 0.3130 & 0.0000 \\
\hline Choline Chloride $60 \%$ & 0.0635 & 0.0635 \\
\hline Sugarex ST Plus² & 0.0150 & 0.0150 \\
\hline Mineral premix with no specific iron source ${ }^{3}$ & 0.1000 & 0.1000 \\
\hline Iron supplement source ${ }^{4}$ & 0.0000 & 0.0000 \\
\hline Vitamin premix ${ }^{5}$ & 0.0460 & 0.0460 \\
\hline Halquinol $60 \%$ & 0.0000 & 0.0250 \\
\hline DenagardTM OT ${ }^{6}$ & 0.0000 & 0.2000 \\
\hline Apralan $100^{7}$ & 0.1500 & 0.0000 \\
\hline Total & 100.00 & 100.00 \\
\hline
\end{tabular}

Notes: ${ }^{1}$ Inert. ${ }^{2}$ Sweetner. ${ }^{3}$ Quantity/kg premix: $110000.00 \mathrm{mg}$ zinc; $15000.00 \mathrm{mg}$ copper; $45000.00 \mathrm{mg}$ manganese; $350.00 \mathrm{mg}$ selenium; $200.00 \mathrm{mg}$ cobalt; $1000.00 \mathrm{mg}$ iodine. ${ }^{4} \mathrm{In}$ starter diets with 50,100 or $150 \mathrm{ppm}$ supplementation of iron, the organic or inorganic sources were added as partial replacement to ground rice hull. ${ }^{5}$ Quantity $/ \mathrm{kg}$ premix: $220.00 \mathrm{mg}$ biotin; $660.00 \mathrm{mg}$ of folic acid; $66000.00 \mathrm{mg}$ niacin; $33000.00 \mathrm{mg}$ pantothenic acid; $7700.00 \mathrm{mg}$ riboflavin; $2200.00 \mathrm{mg}$ thiamine; $4400.00 \mathrm{mg}$ vitamin B6, $44000.00<\mathrm{g}$ vitamin B12; $15400000.00 \mathrm{IU}$ vitamin A; 3300000.00 IU vitamin D3; $88000.00 \mathrm{mg}$ of vitamin E; $6600.00 \mathrm{mg}$ vitamin K. ${ }^{6}$ Association of oxytetracycline hydrochloride (10\%) with Tiamulin hydrogen fumarate $(3.5 \%) .{ }^{7}$ Apramicin $10 \%$.

Source: Elaboration of the authors. 
Table 2. Nutritional composition of pre-starter and starter diets.

\begin{tabular}{lcc}
\hline & Pre-starter (\%) & Starter (\%) \\
\hline Metabolizable energy (kcal/kg) & 3331 & 3331 \\
Crude protein (\%) & 18.47 & 19.43 \\
Digestible lysine (\%) & 1.46 & 1.44 \\
Digestible methionine (\%) & 0.41 & 0.39 \\
Digestible threonine (\%) & 0.95 & 0.96 \\
Digestible tryptophan (\%) & 0.26 & 0.24 \\
Calcium (\%) & 0.75 & 0.73 \\
Available phosphorus (\%) & 0.44 & 0.39 \\
\hline
\end{tabular}

Source: Elaboration of the authors.

The experimental period began on the morning of the tenth day when the animals were weighed after fasting for 12 hours. It lasted for 23 days (31 to 54 days old). The experimental design was a randomized block with seven treatments and six replicates of three animals per experimental unit (pen). The block formation criteria were weight, sex and values of $\mathrm{Hb}$ and $\mathrm{Ht}$.

During the experiment, the animals received starter diet ad libitum (Tables 1 and 2, above). Diets were formulated following the nutritional requirements presented by Rostagno et al. (2005).

Treatments were: starter diet without addition of supplementary iron sources; starter diet supplemented with 50,100 or $150 \mathrm{ppm}$ of iron as iron sulfate monohydrate - S $(34.6 \% \mathrm{Fe})$; starter diet supplemented with 50,100 or $150 \mathrm{ppm}$ iron as iron chelate - ICAPC $(20.5 \% \mathrm{Fe})$. The iron sources were added to replace ground rice hull, and the iron content of the starter diet with no additional supplementary sources being $136 \mathrm{ppm}$.

\section{Performance}

The performance parameters average daily gain (ADG), daily feed consumption (DFC) and feed:gain ratio $(\mathrm{F}: \mathrm{G})$ of piglets from zero to nine days and zero to 23 days of the experimental period, i.e., from 31 to 40 days and from 31 to 54 days old, were evaluated by weighting feed supplied, leftovers and animals after 12 hours of fasting and at the beginning and end of each period. The iron intake was estimated from the feed intake and the amount supplemented as S and as ICAPC in the respective diets.

\section{Blood parameters}

For the analysis of the blood parameters $(\mathrm{Hb}$, $\mathrm{Ht}$, serum iron - FeS, transferrin - TR, latent iron-binding capacity - LIBC, total iron-binding capacity - TIBC and transferrin saturation index - TSI) four blood samples were collected, two on the first nine and two on the last fourteen days of the experiment, that is, on the $6^{\text {th }}, 9^{\text {th }}, 13^{\text {th }}$ and $19^{\text {th }}$ experimental day. Blood samples were taken from the jugular vein with vacuum blood collection tubes $(5 \mathrm{~mL}$ tubes with $3 \%$ EDTA solution and 40x9 needles) and sent to FMVZ`s clinical laboratory in Botucatu.

Hematocrit levels were computed from erythrocyte mean corpuscular volume and bioelectrical impedance figures and the $\mathrm{Hb}$ rates obtained from spectrophotometry. Levels of FeS and LIBC were determined by Labtest's ferrozine colorimetric method and the TR, TIBC and TSI values were computed with the following formulas: $\mathrm{TIBC}=\mathrm{FeS}+\mathrm{LIBC} ; \mathrm{TR}=$ TIBC $\times 0.70 ; \mathrm{TSI}=$ $($ FeS x 100$) \div$ TIBC. 


\section{Iron concentration on tissues}

At the end of the experimental period a piglet from each experimental unit was picked by drawing lots and slaughtered after electrical stunning. Samples of liver and spleen were removed for assessment of iron concentration by flame atomic absorption spectrometry (FAAS). The analyses were performed at the laboratory of chemistry of the Departamento de Química e Bioquímica, Instituto de Biociências, UNESP, Botucatu, using Merck Titrisol standard solution for preparation of the calibration curve. A SHIMADZU spectrometer Model AA-6800, equipped with background absorption correction, deuterium lamp and self-reversal system (SR) was employed. A SHIMADZU iron hollow cathode lamp, operated with $10 \mathrm{~mA}$ of current was used. The wavelength was $248.3 \mathrm{~nm}$ with a spectral resolution of $0.5 \mathrm{~nm}$ (NEVES et al., 2009; COOKBOOK SHIMADZU, 2000).

\section{Statistical analysis}

In order to assess the relative bioavailability of minerals, statistical analyses were performed using Statistical Analysis Systems (1999) MIXED procedure and based on the methodology proposed by Littell et al. (1997). Initially, a general analysis was carried out, the model including only the fixed effect of treatment and random effects of blocks and residues, to estimate the adjusted treatments means. In order to compare the bioavailability of the two sources of supplemental iron to each of the response variables a model was adjusted that included the random effects of blocks and residues, as well as the following fixed components: linear effect of mean supplemental iron intake during the experimental period; interaction between source and linear effect of supplemental iron intake; curve intersection deviation from the zero level of supplemental iron mean response; $y$-axis intersection difference among sources; and the quadratic effect of supplemental iron intake within a source. The fixed effects were tested in the reverse order with respect to the description, following Littell et al. (1997), and were considered significant for a significance level $\leq 5.0 \%$.

\section{Results and Discussion}

No effects on the performance variables were observed for the iron source or for the interaction between iron supply and intake, indicating that the bioavailability of the evaluated iron sources were similar (Table 3).

Table 3. Average daily gain (ADG) and feed:gain ratio $(\mathrm{F}: \mathrm{G})$ of piglets fed diets containing different levels of iron from inorganic and organic sources.

\begin{tabular}{lcccc}
\hline \multirow{2}{*}{ Fe level/Fe source } & \multicolumn{3}{c}{ Period } \\
\cline { 2 - 5 } & ADG $(\mathrm{g})$ & $\mathrm{F}: \mathrm{G}$ & ADG $(\mathrm{g})$ & $\mathrm{F}$ - 23 days \\
\cline { 2 - 5 } & 365.00 & 1.40 & 276.67 & 1.89 \\
\hline $0 \mathrm{ppm}$ / absent & 410.00 & 1.42 & 348.33 & 1.76 \\
$50 \mathrm{ppm}$ / inorganic & 393.33 & 1.42 & 370.00 & 1.80 \\
$100 \mathrm{ppm}$ / inorganic & 425.00 & 1.38 & 383.33 & 1.76 \\
$150 \mathrm{ppm}$ / inorganic & 390.00 & 1.40 & 363.33 & 1.78 \\
$50 \mathrm{ppm}$ / organic & 405.00 & 1.40 & 383.33 & 1.77 \\
$100 \mathrm{ppm}$ / organic & 415.00 & 1.42 & 383.33 & 1.72 \\
$150 \mathrm{ppm}$ / organic & 13.81 & 4.42 & 15.74 & 6.76 \\
CV $(\%)$ & & & & \\
\hline
\end{tabular}

Source: Elaboration of the authors. 
The increase in iron intake with increasing levels of supplementation, regardless of the source used, determined a linear increase in the ADG from zero to nine days $(y=364,2700+0,0734 x$; $\mathrm{P}<0,01)$ and from zero to 23 days $(\mathrm{y}=297,0700$ $+0,1079 \mathrm{x} ; \mathrm{P}<0,01)$, and a linear reduction in the $\mathrm{F}: \mathrm{G}$ ratio from 0 to 23 days $(\mathrm{y}=1,8574-0,0001 \mathrm{x}$; $\mathrm{P}<0,05)$ of the experimental period.

Research has shown that the bioavailability of mineral sources varies with factors such as species, physiological state, interaction between minerals, choice of evaluated response criteria, chemical form and solubility of tested source and several works were carried out comparing organic and inorganic sources of a single mineral in nutritional levels for pigs, especially zinc (HEUGTEN et al., 2003), manganese (KATS et al., 1994) and selenium (MAHAN; CLINE; RICHERT, 1999), showing no differences in the animal performance parameters and thus corroborating the results of this study.

Ettle, Schlegel and Roth (2008) also found improvements in weight gain and feed:gain ratio of animals supplemented with iron when compared to those who did not receive supplementation, a result similar to one obtained in the present experiment.
Lewis, Miller and Wolverton (1996) studied the bioavailability of two sources of iron (iron methionine and iron sulfate) for weanling piglets. Those authors also found a linear increase in feed intake and animal weight gain as well as a linear improvement in feed:gain ratio with increasing mineral supplementation. The weight gain of the piglets increased with the two sources of iron studied. However, for this variable, iron as iron methionine showed $81 \%$ bioavailability relative to iron sulfate.

Piglet hemoglobin and hematocrit counts from the first two blood samples (Table 4) were below the lower limit of the normal range for pigs: 10.0 to $16.0 \mathrm{~g} / \mathrm{dL}$ hemoglobin and 32 to $50 \%$ hematocrit, as defined by Weiss and Wardrop (2010). Piglets fed diets containing $150 \mathrm{ppm}$ iron from inorganic or 100 and $150 \mathrm{ppm}$ of iron from organic sources reached normal values for hematocrit on the $13^{\text {th }}$ and for hemoglobin on the $19^{\text {th }}$ day of the experimental period. On the other hand, regardless of the source used, diets with no iron supplementation or with supplementation with $50 \mathrm{ppm}$ made neither of the two variables reach normal values.

Table 4. Values of hemoglobin $(\mathrm{Hb})$ and hematocrit $(\mathrm{Ht})$ of piglets on the $6^{\text {th }}, 9^{\text {th }}, 13^{\text {th }}$ and $19^{\text {th }}$ experimental day.

\begin{tabular}{lcccccccccc}
\hline & \multicolumn{10}{c}{ Blood collection } \\
\cline { 2 - 13 } & \multicolumn{2}{c}{ 6th day } & \multicolumn{1}{c}{ 9th day } & \multicolumn{1}{c}{ 13th day } & \multicolumn{1}{c}{ 19th day } & \multicolumn{2}{c}{ Mean } \\
\hline \multicolumn{1}{c}{ Fe level/Fe source } & $\begin{array}{c}\mathrm{Hb} \\
(\mathrm{g} / \mathrm{dL})\end{array}$ & $\begin{array}{c}\mathrm{Ht} \\
(\%)\end{array}$ & $\begin{array}{c}\mathrm{Hb} \\
(\mathrm{g} / \mathrm{dL})\end{array}$ & $\begin{array}{c}\mathrm{Ht} \\
(\%)\end{array}$ & $\begin{array}{c}\mathrm{Hb} \\
(\mathrm{g} / \mathrm{dL})\end{array}$ & $\begin{array}{c}\mathrm{Ht} \\
(\%)\end{array}$ & $\begin{array}{c}\mathrm{Hb} \\
(\mathrm{g} / \mathrm{dL})\end{array}$ & $\begin{array}{c}\mathrm{Ht} \\
(\%)\end{array}$ & $\begin{array}{c}\mathrm{Hb} \\
(\mathrm{g} / \mathrm{dL})\end{array}$ & $\begin{array}{c}\mathrm{Ht} \\
(\%)\end{array}$ \\
\hline 0 / absent & 8.19 & 26.61 & 8.06 & 25.67 & 7.43 & 23.22 & 7.92 & 24.67 & 7.90 & 25.04 \\
$50 \mathrm{ppm} /$ inorganic & 8.87 & 28.61 & 8.86 & 28.83 & 8.87 & 29.28 & 9.18 & 29.67 & 8.95 & 29.10 \\
$100 \mathrm{ppm}$ / inorganic & 9.01 & 29.22 & 9.21 & 29.94 & 9.39 & 30.50 & 9.90 & 32.56 & 9.38 & 30.56 \\
$150 \mathrm{ppm} /$ inorganic & 8.99 & 29.67 & 9.49 & 31.50 & 9.92 & 33.00 & 10.60 & 35.28 & 9.75 & 32.36 \\
$50 \mathrm{ppm} /$ organic & 8.72 & 28.50 & 8.81 & 28.78 & 8.68 & 28.78 & 9.11 & 29.78 & 8.83 & 28.96 \\
$100 \mathrm{ppm}$ / organic & 9.31 & 30.67 & 9.59 & 31.50 & 9.69 & 32.28 & 10.57 & 35.17 & 9.79 & 32.40 \\
$150 \mathrm{ppm}$ / organic & 9.12 & 30.33 & 9.58 & 31.56 & 9.76 & 32.06 & 10.21 & 33.72 & 9.67 & 31.92 \\
\hline
\end{tabular}

Source: Elaboration of the authors.

No effects of iron supplementation or of the interaction between iron supply and intake were observed for any of the blood variables (Table 5), demonstrating that iron supplementation on either 
inorganic or organic forms equally affected the blood parameters, suggesting that the bioavailability of the evaluated sources were similar.

The increased levels of iron intake with increasing levels of supplementation, regardless of the source used, determined a linear increase in the values of $\mathrm{Hb}(\mathrm{y}=8,1193+0,0019 \mathrm{x} ; \mathrm{P}<0,01), \mathrm{Ht}(\mathrm{y}$ $=25,9767+0,0072 \mathrm{x} ; \mathrm{P}<0,01), \mathrm{FeS}(\mathrm{y}=41,4819+$ $0,0724 x ; P<0,01)$ and TSI $(y=7,6250+0,0138 x$; $\mathrm{P}<0,01)$ as well as a linear decrease in the values of TR $(y=412,4000-0,0325 x ; P<0,01)$, LIBC $(\mathrm{y}=547,8600-0,1191 \mathrm{x} ; \mathrm{P}<0,01)$ and TIBC $(\mathrm{y}=$ $589,1500-0,0464 x ; \mathrm{P}<0,01)$.

Table 5. Blood count of hemoglobin (Hb), hematocrit (Ht), transferrin (TR), latent iron binding capacity (LIBC), total iron binding capacity (TIBC), serum iron (FeS) and transferrin saturation index (TSI) in pigs fed diets containing different levels of iron from inorganic and organic sources.

\begin{tabular}{lccccccc}
\hline \multirow{2}{*}{ Fe level/Fe source } & \multicolumn{7}{c}{ Blood parameters } \\
\cline { 2 - 8 } & $\begin{array}{c}\mathrm{Hb} \\
(\mathrm{g} / \mathrm{dL})\end{array}$ & $\begin{array}{c}\mathrm{Ht} \\
(\%)\end{array}$ & $\begin{array}{c}\text { TR } \\
(\mathrm{m} / \mathrm{dL})\end{array}$ & $\begin{array}{c}\text { LIBC } \\
(\mu \mathrm{g} / \mathrm{dL})\end{array}$ & $\begin{array}{c}\text { TIBC } \\
(\mu \mathrm{g} / \mathrm{dL})\end{array}$ & $\begin{array}{c}\text { FeS } \\
(\mu \mathrm{g} / \mathrm{dL})\end{array}$ & $\begin{array}{c}\text { TSI } \\
(\%)\end{array}$ \\
\hline $0 /$ absent & 7.90 & 25.04 & 416.80 & 561.08 & 595.43 & 34.35 & 6.09 \\
$50 \mathrm{ppm}$ / inorganic & 8.95 & 29.10 & 397.92 & 498.81 & 568.45 & 69.64 & 13.24 \\
$100 \mathrm{ppm}$ / inorganic & 9.38 & 30.56 & 384.31 & 445.49 & 549.01 & 103.53 & 19.70 \\
$150 \mathrm{ppm}$ / inorganic & 9.75 & 32.36 & 378.05 & 440.03 & 540.07 & 100.04 & 18.85 \\
$50 \mathrm{ppm} /$ organic & 8.83 & 28.96 & 404.79 & 511.20 & 578.27 & 67.07 & 12.29 \\
$100 \mathrm{ppm}$ / organic & 9.79 & 32.40 & 388.94 & 456.33 & 555.63 & 99.29 & 18.60 \\
$150 \mathrm{ppm}$ / organic & 9.67 & 31.92 & 386.09 & 446.75 & 551.56 & 104.81 & 19.72 \\
$\mathrm{CV}(\%)$ & 13.84 & 15.70 & 8.40 & 18.54 & 8.40 & 60.58 & 77.43 \\
\hline
\end{tabular}

Source: Elaboration of the authors.

Comparing organic with inorganic sources of minerals ( $\mathrm{Cu}, \mathrm{Zn}, \mathrm{Fe}, \mathrm{Mn}$ and $\mathrm{Se}$ ) Muniz et al. (2010) found no differences in $\mathrm{Hb}$ and $\mathrm{Ht}$ values for pigs. Different results were found by Kegley et al. (2002) who compared piglet oral supplementation with iron methionine against oral supplementation with iron sulfate and found higher values of $\mathrm{Hb}$ and $\mathrm{Ht}$ in animals given iron methionine. However, Lewis, Miller and Wolverton (1996) when assessing the bioavailability of iron from iron methionine and from iron sulfate for piglets noted that, based on $\mathrm{Hb}$ concentration, iron methionine showed 68\% iron bioavailability with respect to iron sulfate.

In a study of minerals from organic and inorganic sources ( $\mathrm{Zn}, \mathrm{Cu}, \mathrm{Fe}, \mathrm{Mn}, \mathrm{Se})$ for nursery piglet, Creech et al. (2004) found lower Hb concentration in animals fed a diet containing low levels of minerals from inorganic sources with respect to nutritional requirements when compared to $\mathrm{Hb}$ levels in animals fed a diet containing low levels of chelated minerals, suggesting a greater bioavailability of minerals from organic sources. Different results were found in the present study.

Lewis, Miller and Wolverton (1996) observed that anemic weaned piglets supplemented with 50, 100 and $200 \mathrm{ppm}$ iron showed a linear increase in $\mathrm{Hb}$ values with an increase in the amount of supplemented iron. Yu, Huang and Chiou (2000) found in weaned piglets a linear increase of $\mathrm{Hb}$ levels and a linear reduction of TIBC with an increasing level of iron supplementation.

Underwood and Suttle (1999) described four stages of the physiological effects of iron deficiency. In the first stage of depletion, the iron in the liver and kidneys and stored as ferritin and hemosiderin is reduced, but the blood parameters remain 
unchanged. Its duration depends on the starting iron stock. The second stage is characterized by changes in blood parameters, with a decrease in the values of $\mathrm{Hb}, \mathrm{Ht}$, myoglobin, and FeS and an increase in TR concentration, in addition to a continuing reduction of the iron stock. In the third stage dysfunction occurs when iron-dependent metabolic functions, such as blood and muscle oxygen transport, hormone synthesis and immune defense, are impaired. The fourth stage is characterized by a decrease in feed intake and in growth, plus lethargy and symptoms of iron deficiency anemia. This information explains the results of the present experiment, since there was a linear improvement in $\mathrm{ADG}$ and $\mathrm{F}: \mathrm{G}$, and linear effects on all blood variables with increased consumption of iron supplementation, regardless of the source studied.

When TR is completely saturated with a known concentration of iron, the total amount of mineral attached to it represents the TIBC, and the increase in TR concentration increases the TIBC values. Serum TR is normally unsaturated because typically $30 \%$ of the available sites are filled. The concentration of FeS defines the iron transported in serum bound to TR and is found to be low under iron deficiency anemia.
In anemia, TR levels are kept high in an attempt to increase absorption of iron. Stored iron is requested in order to meet the demands of erythropoiesis and depends on this carrier protein, but its saturation percentage is low. Under these conditions, LIBC and TIBC also increase, explaining the linear decrease of these variables with increasing diet levels of iron as observed in the present experiment. According to Furugouri (1972a, 1972b), the synthesis of TR is related to iron deficiency anemia, and to indexes like LIBC, TIBC and TSI, which are considered sensitive indicators for the assessment of iron metabolism.

Furugouri (1971) has defined the values considered normal for TIBC (440-640 mg/100 mL), FeS (49-197 mg/100 mL) and TSI (8-36\%) in pigs between 70 and $90 \mathrm{~kg}$. The values observed in this experiment led to the conclusion that except for animals that did not have diet iron supplementation, those parameters remained within the normal range.

Liver and spleen iron concentrations were not affected by the source of iron supplementation nor by the interaction between iron supply and intake, suggesting a similarity in the bioavailability of the studied iron sources (Table 6).

Table 6. Concentration of iron in the liver and spleen of pigs fed diets containing different levels of iron from inorganic and organic sources.

\begin{tabular}{lcc}
\hline \multicolumn{1}{c}{ Fe level/Fe source } & \multicolumn{2}{c}{ Tissue } \\
\cline { 2 - 3 } & Liver $(\mathrm{ppm})$ & Spleen $(\mathrm{ppm})$ \\
\hline $0 /$ absent & 130.74 & 577.25 \\
$50 \mathrm{ppm} /$ inorganic & 125.74 & 373.76 \\
$100 \mathrm{ppm} /$ inorganic & 175.22 & 499.28 \\
$150 \mathrm{ppm} /$ inorganic & 145.52 & 338.18 \\
$50 \mathrm{ppm} /$ organic & 110.95 & 341.50 \\
$100 \mathrm{ppm} /$ organic & 208.03 & 433.24 \\
$150 \mathrm{ppm} /$ organic & 155.42 & 387.68 \\
CV $(\%)$ & 54.34 & 39.34 \\
\hline
\end{tabular}

Source: Elaboration of the authors.

Increases in pig liver iron levels with increasing levels of supplementation, demonstrating a high storage capacity of that organ, have been noted by several authors (FURUGOURI, 1972a; RINCKER 
et al., 2004; YU; HUANG; CHIOU, 2000) but not observed in this experiment.

Since the levels of non-heme iron in liver and spleen represent the largest iron reservoir of the organism, in situations of deficiency, iron from those organs is mobilized (RATH; FINCH, 1948), playing an important role in maintaining $\mathrm{Hb}$, myoglobin and iron-containing enzymes levels. On the other hand, Furugouri (1973a) stated that the spleen is the main site of destruction of red blood cells and it stores iron released from those cells, playing a more important role in this function than as a local storage iron.

Furugouri (1973b) studied the effect of fasting, comparing pigs placed under 15 days of restricted feeding followed by 15 consecutive days of ad libitum feeding with animals fed ad libitum for 30 days, noting that the iron concentrations were higher in the livers and in the spleens of animals that underwent fasting than in those fed ad libitum. However, the mean weight of the liver of fasting animals was about half that of animals fed diets ad libitum (1,298 x $686 \mathrm{~g})$. There was no difference between groups regarding total liver iron volume, indicating that the increase in iron concentration may have been due to the smaller weight of the liver. The weight of the spleen was unaffected by fasting, but there was an increase in the concentration of total iron, from $184 \mathrm{ppm}$ in animals fed ad libitum to $275 \mathrm{ppm}$ in animals under fasting, suggesting that animals receiving lower iron concentrations tend to have the volume stored in their spleens increased.

The estimation of actual liver and spleen iron reserves may have been compromised because the weights of those organs were not measured. In the present experiment, although no significant difference were detected, the animals that did not receive iron supplementation showed a numerically greater value for iron in the spleen.

In conclusion, in weaned piglets, the bioavailability of iron from iron carbo-aminophospho-chelate is similar to the one from iron sulfate monohydrate.

\section{References}

ACDA, S. P.; CHAE, B. J. A review on the applications of organic trace minerals in pig nutrition. Pakistan Journal of Nutrition, Faisalabad, v. 1, n. 1, p. 25-30, 2002.

ASHMEAD, H. W. Nutrição e minerais aminoácidos quelados. São Paulo: Attar, 1996. 318 p.

CHURCH, D. C.; POND, W. G. Basic animal nutrition and feeding. 3. ed. New York: John Wiley \& Sons, 1982. $403 \mathrm{p}$.

COOKBOOK SHIMADZU - Operation manual: atomic absorption spectrophotometer AA-6800, SHIMADZU, 2000. $67 \mathrm{p}$.

CREECH, B. L.; SPEARS, J. W.; FLOWERS, W. L.; HILL, G. M.; LLOYD, K. E.; ARMSTRONG, T. A.; ENGLE, T. E. Effect of dietary trace mineral concentration and source (inorganic vs. chelated) on performance, mineral status, and fecal mineral excretion in pigs from weaning through finishing. Journal of Animal Science, Champaign, v. 82, n. 7, p. 2140-2147, 2004.

ETTLE, T.; SCHLEGEL, P.; ROTH, F. X. Investigations on iron bioavailability of different sources and supply levels in piglets. Journal of Animal Physiology and Animal Nutrition, Berlin, v. 92, n. 1, p. 35-43, 2008.

FURUGOURI, K. Developmental changes in the nonheme iron composition of the liver and spleen in piglets. Journal of Animal Science, Champaign, v. 36, n. 2, p. 265-270, 1973a.

Effect of elevated dietary levels of iron on iron store in liver, some blood constituents and phosphorus deficiency in young swine. Journal of Animal Science, Champaign, v. 34, n. 4, p. 573-577, 1972a.

Effect of prolonged fasting on iron stores and blood constituents in young swine. Journal of Animal Science, Champaign, v. 37, n. 3, p. 697-700, 1973 b.

Normal values and physiological variations of plasma iron and total iron-binding capacity in pigs. Journal of Animal Science, Champaign, v. 32, n. 4, p. 667-672, 1971.

Plasma iron and total iron-binding capacity in $\overline{\text { piglets }}$ in anemia and iron administration. Journal of Animal Science, Champaign, v. 34, n. 3, p. 421-426, 1972b.

HEUGTEN, E. V.; SPEARS, J. W.; KEGLEY, J. D. W.; QHRESHI, M. A. Effects of organic forms of zinc on growth performance, tissue zinc distribution, and immune response of weanling pigs. Journal of Animal Science, Champaign, v. 81, n. 8, p. 2063-2071, 2003. 
KATS, L. J.; NELSSEN, J. L.; GOODBAND, R. D.; TOKACH, M. D.; FRIESEN, K. G.; OWEN, K. Q.; RICHERT, B. T.; DRITZ, S. S. Effect of chelated manganese on growth performance and carcass of finishing pigs. Kansas Swine Day, Garden City, p. 165-167, 1994. Available at: <http://hdl.handle. net/2097/3337>. Accessed at: 8 nov. 2010.

KEGLEY, E. B.; SPEARS, J. W.; FLOWERS, W. L.; SCHOENHERR, W. D. Iron methionine as a source of iron for the neonatal pig. Nutrition Research, Philadelphia, v. 22, n. 10, p. 1209-1217, 2002.

LEWIS, A.; MILleR, P. S.; WOLVERTON, C. Bioavailability of iron in two different sources for weanling pigs. Nebraska: University of Nebraska Animal, 1996. Available in: <http://digitalcommons.unl. edu/coopext_swine/187>. Accessed in: 17 oct. 2010.

LINDER, M. C. Nutrition and metabolism of the trace elements. In: Nutritional biochemistry and metabolism with clinical applications. 2. ed. New York: Elsevier Science Publishing Company, 1991. cap. 7, p. 215-276.

LITTELL, R. C.; HENRY, P. R.; LEWIS, A. J.; AMMERMAN, C. B. Estimation of relative bioavailability of nutrients using SAS procedures. Journal of Animal Science, Champaign, v. 75, n. 10, p. 2672-2683, 1997.

MAHAN, D. C.; CLINE, T. R.; RICHERT, B. Effects of dietary levels of selenium-enriched yeast and sodim selenite as selenium source fed to growing-finishing pigs on performance, tissue selenium, serum glutathione peroxidase activity, carcass characteristics, and loin quality. Journal of Animal Science, Champaign, v. 77, n. 8, p. 2172-2179, 1999.

MCDOWELL, L. R. Iron. In: Minerals in animal and human nutrition. 2. ed. San Diego: Academic Press Inc., 2003. cap. 7, p. 203-233.

MUNIZ, M. H. B.; BERTO, D. A.; AUGUSTO, R. M. N.; TRINDADE NETO, M. A.; WECHSLER, F. S.; LO TIERZO, V.; HAUPTLI, L. Organic and Inorganic mineral sources for weanling piglets. Ciência Rural, Santa Maria, v. 40, n. 2, p. 163-2168, 2010.
NEVES, R. C. F.; MORAES, P. M.; SALEH, M. A. D.; LOUREIRO, V. R.; SILVA, F. A.; BARROS, M. M.; PADILHA, C. C. F.; JORGE, S. M. A.; PADILHA, P. M. FAAS determination of metal nutrients in fish feed after ultrasound extraction. Food Chemistry, Berlin, v. 113, n. 2, p. 679-683, 2009.

RATH, C. E.; FINCH, C. A. Sternal marrow hemosiderin: a method for the determination of available iron stores in man. Journal of Laboratory and Clinical Medicine, St. Louis, v. 33, n. 1, p. 81-86, 1948.

RINCKER, M.J.;HILL, G. M.;LINK, J.E.; ROWNTREE, J. E. Effects of dietary iron supplementation on growth performance, hematological status, and whole-body mineral concentrations of nursery pigs. Journal of Animal Science, Champaign, v. 82, n. 11, p. 3189-3197, 2004.

ROSTAGNO, H. S.; ALBINO, L. F. T.; DONZELE, J. L.; GOMES, P. C.; OLIVEIRA, R. F.; LOPES, D. C.; FERREIRA, A. S.; BARRETO, S. L. T. Tabelas brasileiras para aves e suinos: composição de alimentos e exigências nutricionais. 2. ed. Viçosa: UFV, 2005. 186 p.

SCHIAVON, S.; BAILONI, L.; RAMANZIN, M.; VICENZI, R.; SIMONETTO, A.; BITTANTE, G. Effect of proteinate or sulphate mineral source on trace elements in blood and liver of piglets. Journal of Animal Science, Champaign, v. 71, n. 1, p. 131-139, 2000.

STATISTICAL ANALYSIS SYSTEMS - SAS. User's guide: statistics. Companion for the Microsoft Windows Environment, version 6.12. Cary: SAS Institute, 1999. CD-ROM.

SVOBODA, M.; DRÁBEK, J. Efficiency of voluntary consumption of amino acid chelated iron in preventing anaemia of suckling piglets. Acta Veterinarya Brno, Brno, v. 72, n. 4, p. 499-507, 2003.

UNDERWOOD, E. J.; SUTTLE, N. F. The mineral nutrition of livestock. 3. ed. Wallingford: CABI, 1999. $614 \mathrm{p}$.

WEISS, D. J.; WARDROP, K. J. Schalm's veterinary hematology. 6. ed. Wile Blackwell, 2010. 1232 p.

YU, B.; HUANG, W. J.; CHIOU, P. W. S. Bioavailability of iron from amino acid complex in weanling pigs. Animal Feed Science and Technology, Amsterdam, v. 86, n. 1-2, p. 39-52, 2000. 